\title{
Modelling the Impacts of Climate Change on the Yield of Crops
}

\author{
Oluwaseun Ayodele ILESANMI ${ }^{1}(\varpi)$ \\ ${ }^{1}$ Agricultural \& Bioresources Engineering, Federal University Oye Ekiti, Nigeria \\ ${ }^{1}$ Agricultural \& Environmental Engineering, Federal University of Technology, Akure, Nigeria \\ oluwaseun.ilesanmi@fuoye.edu.ng \\ Philip Gbenro OGUNTADE ${ }^{2}$ \\ Obafemi Olutola OLUBANJO ${ }^{3}$ \\ ${ }^{2,3}$ Agricultural \& Environmental Engineering, Federal University of Technology, Akure, \\ Nigeria
}

\begin{abstract}
This study shed light on the impact change(s) experienced in our climate system will have on the level of crop productivity in the immediate period and the nearest future. Nigeria was used as a case study. An observed climatic dataset was obtained and utilized alongside 20-year Cassava, Rice, and Soybean yield data to develop models applied in this study to estimate future crop yield. Four (4) statistically downscaled and bias-corrected Global Climate Models (GCMs): National Oceanic and Atmospheric Administration (NOAA), Japan Agency for Marine-Earth Science and Technology (MIROC5), Irish Centre for High-End Computing (ICHEC), and Norwegian Climate Centre (NCC) performed simulations for the period 1985-2100 under the Representative Concentration Pathway (RCP8.5). These were modeled to predict future yields of Cassava, Rice and Soybean in 2020-2050 and 2070-2100 for the 36 states in Nigeria and the FCT. Eighty-nine (89) empirical models were developed to estimate the yields of the three crops earlier mentioned across Nigeria, with their coefficient of determination $\left(\mathrm{R}^{2}\right)$ ranging between $15 \%$ 99\%. The result showed an increase of $3.91 \%(\mathrm{P}<0.001), 0.08,1.79(\mathrm{P}<0.1)$, and a decrease of $0.93 \%$ for cassava yield for ICHEC, MIROC, NOAA, and NCC, respectively. It also projected an increase in yield of $8.88 \%(\mathrm{P}<0.001), 7.77 \%(\mathrm{P}<0.001), 6.62 \%(\mathrm{P}<0.001)$, and $8.85 \%$ $(\mathrm{P}<0.001)$ for Rice yield using climatic data from ICHEC, MIROC, NOAA, and NCC respectively. Soybean increase in yield is $2.81 \%(\mathrm{P}<0.01), 5.84 \%(\mathrm{P}<0.001), 11.38(\mathrm{P}<0.001)$, and $9.06 \%(\mathrm{P}<0.001)$ for ICHEC, MIROC, NOAA, and NCC, respectively.
\end{abstract}

Keywords: Climate Change, Empirical models, RCP8.5, Yield, Food Security, Crop production

\section{INTRODUCTION:}

Climate change is defined as an observable, significant, and long-term change in weather patterns that occurs across timescales, which can range from tens of years to 
Journal of Digital Food, Energy \& Water Systems, 2 (2): 55-76, 2021

ISSN 2709-4529

(c) Centre for Cyber Physical Food, Energy \& Water Systems

probably millions of years. It could be a shift in accustomed conditions of the weather or its distribution around the accustomed conditions either positively or negatively. Many such shifts could also be seen locally or globally [1].

Knowing how climate varies historically and in the future is very important in developmental studies, especially in crop and water resources, as these affect the socioeconomic state of an area. [2,3]. Climate change studies show that crop water use, efficiency, and yield are likely to change. Although there are drought-resistant crops, rainfall deficit or lack of it or its unpredictability, which has been noticed in recent research, does not help. These rainfall fluctuations tend to promote temperature rise, which can also influence the outbreak of crop diseases that can negatively impact yield [4]. Crops can adapt to mean climatic variations but in some instances react negatively to extreme climatic conditions. These reactions to harsh or extreme conditions are usually more severe than reactions to mean climatic variations $[5,6,7$, 8].

Climate change's impact on food production, water resources, crop development, and productivity has been widely documented in numerous parts of the globe. The critical issues impacted by the changing climate, such as crop production and food security, have gotten a lot of attention they deserve, with studies forecasting possible future impacts on agricultural productivity using crop models in conjunction with climate models [9].

In accordance with IPCC (Intergovernmental Panel on Climate Change) 2007 report, Global climate change will result from increased anthropogenic greenhouse gas emissions. This change is expected to increase global temperature, change precipitation patterns and quantities. It will also increase the frequency and intensity of significant natural hazards such as droughts, heatwaves, floods, and fires [10], keeping in mind that living organisms, including crops, rely on water availability for survival [11]. Therefore, more extensive impact analyses are needed, with probabilistic output from ensembles of climate models to represent better uncertainty and clear communication of what we know and don't know about how regional climate may change $[5,12]$.

Dependency on rainfall has also become a critical hindrance for developing countries' long-term food production programs [13, 14]. Crop production in the region is mainly subsistent and sensitive to climate with little coping or adaptive strategies [15]. Climatic scenarios, a significant player in crop production, can hardly be controlled, and projected deviations from historical means might likely affect production level and capacity [16].

In studying how climate change impacts our environment, the Intergovernmental Panel on Climate Change (IPCC) has developed scenarios with distinct predicted 
Journal of Digital Food, Energy \& Water Systems, 2 (2): 55-76, 2021

ISSN 2709-4529

(c) Centre for Cyber Physical Food, Energy \& Water Systems

environmental conditions for the future. Various aspects of our environment can be analyzed using these scenarios. The climate change research community has developed four (4) new tools for studying climate change called scenarios, designated Representative Concentration Pathways (RCPs), for the IPCC's Fifth Assessment Report [17]. Details of this report which describes each of the four (4) scenarios hereafter referred to as RCP can be found in the IPCC 2013 reports.

The effects of climate change on crop yield are frequently linked to its effects on water productivity and soil water balance. Temperature and rainfall will be affected by global warming, directly impacting soil moisture levels and groundwater levels. [18].

Food production is influenced by more than just rainfall and temperature fluctuations. At regional and global dimensions, population growth and economic development trajectories will influence future climate change impacts and, at the same time, agricultural responses to changing climate circumstances. [19, 20]. Recent research has also posited that the effects of these climatic changes in some places of the United States and Canada are not wholly negative.; greater agricultural outputs are projected as $\mathrm{CO}_{2}$ levels rise and the length of the growing season lengthens [21, 22]. Similar studies carried out in the Ondo State region of Nigeria through empirical evidence strongly showed that climate variability and climate change, among other factors, negatively affected primary fruit, tuber crops' outputs, and cropping acreage [23].

Studies in Indonesia also found out that rice production in Indonesia is vulnerable to changing climate, and it creates the need to implement strategies to adapt to these changes [24]. Africa, unfortunately, having the little adaptive capability, is one of the most sensitive continents to climate change and climate parameter fluctuation. Africa's weak adaptation capability has been exacerbated by development constraints such as endemic poverty, complex governance and institutional features; restricted access to capital, including markets, infrastructure, and technology; ecological degradation; and complex disasters and conflicts, increasing the continent's vulnerability to projected climate change [25].

Agricultural Production is a vital source of income and employment for numerous Nigerian households and a vital source of food. As previously stated, climate change poses a significant threat to this industry. If this concern is not addressed, it could result in increased unemployment, food scarcity, and even hunger among small-scale farmers. The Agro-allied industry is an integral contributor to the Nigerian economy, and farmers' incapacity to grow crops in sufficient amounts can translate to severe ramifications for people's livelihoods and economies. As a result, it is necessary to; Increase crop producers' per capita income by facilitating the adoption of effective adaptation mechanisms to cope with climatic unpredictability in light of current and 
Journal of Digital Food, Energy \& Water Systems, 2 (2): 55-76, 2021

ISSN 2709-4529

(c) Centre for Cyber Physical Food, Energy \& Water Systems

likely worsening climatic conditions and also, maintaining while improving crop production levels in light of current and likely deteriorating climatic conditions.

This research aims to take a look at the consequences of climate change on Cassava, Rice, and soybean. It further seeks to determine the likely effects of these future scenarios on future yields of these crops, allowing us to devise adaptive approaches to maximize results' value.

\section{Methodology}

\subsection{Area of study}

The country Nigeria is considered for this research. The region is found between $4^{\circ} \mathrm{N}$ and $14^{\circ} \mathrm{N}$ latitudes and $2^{\circ} \mathrm{E}$ and $15^{\circ} \mathrm{E}$ longitudes (Figure 1)

The country's southern region is defined by a coastline that runs from the southwest to the southeast and includes Africa's largest delta, the Niger delta. It has a tropical rainforest environment with annual precipitation ranging from 60 to 80 inches $(1524 \mathrm{~mm}$ to $2032 \mathrm{~mm})$, with saline water in the south section of the rainforest zone, which is known as the mangrove swamp forest due to the proximity of a large amount of mangrove within the zone. A freshwater wetland and the rain forest are located to the north. This region is characterized by uneven, steep terrain that stretches from the west to the Benue Mountains in the east.

The Savannah Zone, located north of Nigeria's tropical timberland region, represents the start of Northern Nigeria, with approximate annual precipitation ranging from $500 \mathrm{~mm}$ to $1600 \mathrm{~mm}$. The Guinea Savannah, with long grasses, trees, and a humid environment, is followed by the Sudan Savannah, with shorter grasses and more scattered, drought-resistant trees like the baobab, tamarind, and acacia. The third, known as the Sahel savannah, is found in the country's far north and has a desert environment with annual precipitation of less than $500 \mathrm{~mm}$. The northern part of Nigeria's geography is lowland, with a relatively level terrain that stretches from Lake Chad to the Sokoto lowlands. 
Journal of Digital Food, Energy \& Water Systems, 2 (2): 55-76, 2021

ISSN 2709-4529

(c) Centre for Cyber Physical Food, Energy \& Water Systems

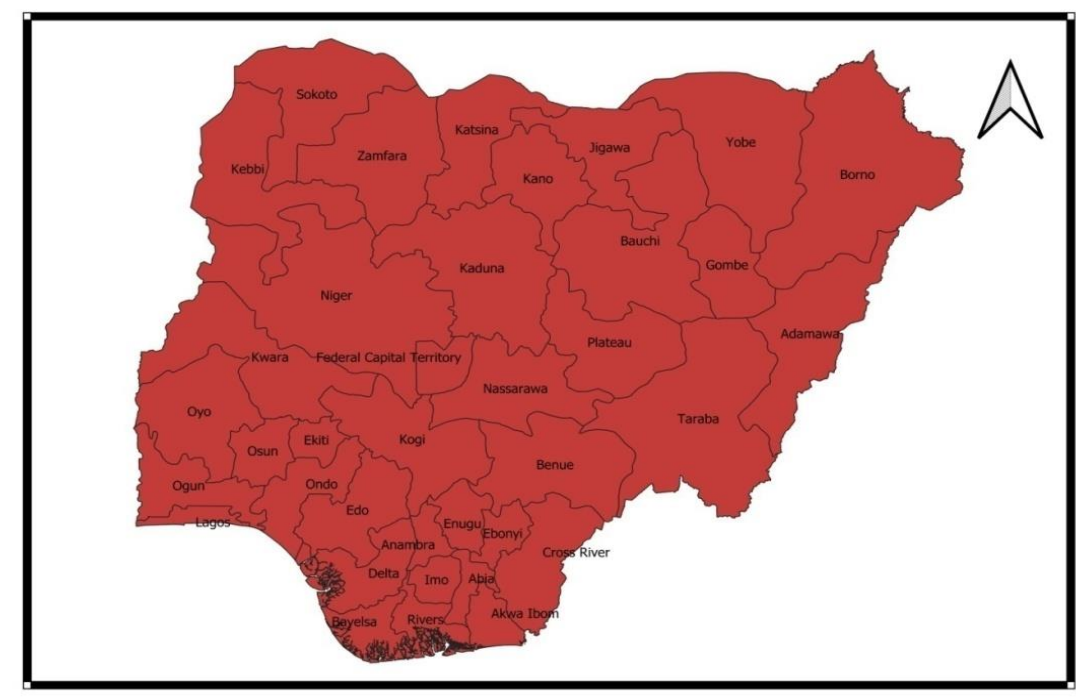

Figure 1: Map of Study Area

\subsection{Materials:}

The records of the crops', i.e. Cassava, Rice, and Soybean yield covering 20 years, were sourced across the 36 states of Nigeria and the FCT through the Agricultural Development Project (ADP). The three crops were selected based on their level of consumption, production, cultivation, commercial value, and data availability in Nigeria.

Climatic data for this research was in two datasets. One dataset was used to observe the present-day climate and the locations where crops are grown across Nigeria. The second was climate modeled data (statistically downscaled at the weather station level), usually called GCM (Global Climate Models). The observation dataset was the $0.5^{\circ} \times 0.5^{\circ}$ resolution monthly precipitation, minimum and maximum temperature gridded dataset from January through December for 1985 to 2100 collected from the Climate Research Unit, University of East Anglia [26]. The GCMs from the IPCC's RCP 8.5 scenario was used as a basis for the calculations and analyses for this research. (RCPs are a set of scenarios developed by the IPCC working groups based on emission and radiative levels by 2100 . The data were bias-corrected to make model estimates/simulations closer to the observed values $[27,28]$. There are 4 RCPs, the minor emission/radiative 
Journal of Digital Food, Energy \& Water Systems, 2 (2): 55-76, 2021

ISSN 2709-4529

(C) Centre for Cyber Physical Food, Energy \& Water Systems

level is RCP2.6, and the highest emission/radiative level is RCP8.5). The GCMs are detailed below;

Table 1: List of GCMs applied in the study

\begin{tabular}{|l|l|l|}
\hline Modeling group & IPCC Model ID & Resolution \\
\hline $\begin{array}{l}\text { Japan Agency for Marine-Earth Science } \\
\text { and Technology }\end{array}$ & MAROC & $1.4^{0} \times 1.4^{0}$ \\
\hline Norwegian Climate Centre & NCC & $2.5^{0} \times 1.9^{0}$ \\
\hline $\begin{array}{l}\text { National Oceanic and Atmospheric } \\
\text { Administration (USA) }\end{array}$ & NOAA & $2.5^{0} \times 2.0^{0}$ \\
\hline $\begin{array}{l}\text { Irish Centre for High-End Computing } \\
\text { (Europe) }\end{array}$ & ICHEC & $1.25^{0} \times 1.25^{0}$ \\
\hline
\end{tabular}

The data for this research covered three time-periods: i) past/present (2000), (average values between 1985 - 2015), ii) intermediate (2050) (average values between 20202050) and, future (2100) (average values between 2070-2100).

\subsection{Methods:}

Among empirical models, multiple linear regression (MLR) models are tools used in carrying out analyses regarding climate and soil conditions to determine their effects on crop yield. [29, 30]. This method was applied in this study in developing models to estimate Cassava, Rice, and Soybean yield in Nigeria.

\subsubsection{Regression Analysis - Multiple Linear Regression (Development of Crop} Yield models).

The development of crop yield models was done using this medium. With the exception that numerous independent variables are utilised in the model, multiple linear regression analysis is quite similar to simple linear regression analysis. Multiple linear regression is mathematically represented as:

$$
Y=a+b X_{1}+c X_{2}+d X_{3}
$$

(1)

Where: 
Journal of Digital Food, Energy \& Water Systems, 2 (2): 55-76, 2021

ISSN 2709-4529

(C) Centre for Cyber Physical Food, Energy \& Water Systems

$Y$ - Yield; $X_{1}, X_{2}, X_{3}$ - Climatic variables; $a$ - Model Constant; $b, c, d$ - Model Coefficients

\subsubsection{Temporal/Trend Analysis}

The Mann - Kendall test is a non-parametric one, usually deployed to detect and quantify trends in datasets. This technique was deployed to estimate the significant trend in the observed yield of the crops through the periods which the research work covered. The trend analysis was carried out on a monthly and annual basis. The value of the trend was obtained by using Sen's non-parametric test, an integral part of the Mann-Kendall software. The procedures are as outlined by [2], [3] and [31].

\section{RESULTS AND DISCUSSIONS}

\subsection{Developed Crop models}

Numerous models were developed, and the models with the best Coefficient of determination and incorporating the highest numbers model variables were selected for each crop and State to give reasonable estimations. Selected models were used to estimate the yields of the three earlier mentioned crops across Nigeria, with their coefficient of determination $\left(\mathrm{R}^{2}\right)$ ranging between $15 \%$ and $99 \%$.

\subsection{Crop Yield Changes under ICHEC Climate Scenario}

Applying climatic data downscaled from the Irish Centre for High-End Computing (ICHEC) in estimating the yield of Cassava, Rice and Soybean across Nigeria, between the periods as described in the methods, the output from the analysis showed that the yield of Cassava is significantly on the increase in most of the states of the except Abia, Adamawa, Bauchi, Bayelsa, Benue, Borno, Delta, Ebonyi, Edo, Rivers Sokoto, Taraba and Zamfara states which presented a significant decrease in their case. This scenario presented itself in [32], where the study reported that future climate changes positively benefitted parts of the United state. This positive benefit was mainly in The Pacific North-West and Northern Great Plains. On the other hand, the southeast coastal regions were severely affected by expected climate changes. Also, [33] and [34] projected an increase in Cassava and Oil Palm yield in Nigeria from 2020 beyond due to the effect of climate change on temperature and precipitation.

The yield of Rice was also projected to significantly reduce in nine (9) states, namely Adamawa, Bayelsa, Borno, Kaduna, Kebbi, Lagos, Ondo, Oyo, and Yobe, with three 
Journal of Digital Food, Energy \& Water Systems, 2 (2): 55-76, 2021

ISSN 2709-4529

(c) Centre for Cyber Physical Food, Energy \& Water Systems

(3) others experiencing a non-significant reduction in yield. However, twenty-one other states were projected to experience an increase in rice yield. [33] reported that the yield of cereals might reduce due to climate change impacting temperature and precipitation, which is in line with results obtained in this study regarding Rice.

In the projection for Soybean yield, there were also instances of significant increase and decrease. A study by [35] projected that rising temperatures would lower global wheat yields by $6.0 \%$, rice yields by $3.2 \%$, maize yields by $7.4 \%$, and soybean yields by $3.1 \%$, with outcomes highly variable across crops and geographical locations, with some positive impact estimates.

The increase in Cassava yield ranged between $1.71 \%$ and $11.35 \%$, while the decrease was between $3.11 \%$ and $11.82 \%$. For Rice, the growth is between 0.12 and 11.74 , reducing between $0.64 \%$ and $9.77 \%$. In the case of Soybean, the yield increase is between $0.59 \%$ and $12.35 \%$, while the decrease ranged from $0.87 \%$ and $11.58 \%$. These projected changes in yield are most significant $(\mathrm{P}<0.001)$, as shown in Table 2 .

\subsection{Crop Yield Changes under NOAA Climate Scenario}

In using the climate data from National Oceanic and Atmospheric Administration (NOAA), the yield of Cassava showed a significant decrease in Abia, Adamawa, Bauchi, Bayelsa, Benue, Borno, Delta, Ebonyi, Edo, Kaduna, Kogi, Nassarawa, Rivers Sokoto, Taraba, and Zamfara states, agreeing with [23], where climate change harmed the yield of tuber crops, while the other Nineteen states and the FCT showed a marked and significant increase in yield. [36] Showed that the impact of changing climate patterns on crops using wheat and maize as case studies with respect to two (2) Representative Concentration Pathways (RCP4.5 and RCP8.5) projected both an increase and decrease in yield. These projected changes in yield are significant $(\mathrm{P}<0.001)$ except in Kaduna, Kogi, and Plateau State. The growth is from $0.69 \%$ to $11.33 \%$, while the decrease ranges between $0.17 \%$ and $11.69 \%$.

Rice projections exhibited a significant decrease in Adamawa, Bayelsa, Borno, Ekiti, Kaduna, Kebbi, Ondo, Yobe, and Zamfara with FCT (3) others Gombe and Oyo, experiencing a non-significant reduction in yield. In contrast, the other states predicted an increase in output. The observed increase ranged from $0.5 \%$ to $11.39 \%$, whereas the decrease was between $0.47 \%$ and $10.39 \%$.

Ekiti, FCT, Gombe, Kogi, Lagos, Niger, Oyo, and Sokoto returned a projected decrease between $1.18 \%$ and $10.71 \%$ for Soybean. In comparison, the other twelve (12) states with Soybean production predicted significant increases ranging from $0.94 \%$ to $11.86 \%$. These expected changes are significant $(\mathrm{P}<0.001)$, as shown in Table 3 . 
Journal of Digital Food, Energy \& Water Systems, 2 (2): 55-76, 2021

ISSN 2709-4529

(C) Centre for Cyber Physical Food, Energy \& Water Systems

\subsection{Crop Yield Changes under MIROC Climate Scenario}

The yield projection using climatic data from the Japan Agency for Marine-Earth Science and Technology (MIROC) mirrors results from NOAA yield analysis. Cassava yield is predicted to increase as the years go by in twenty (20) states, with the increase projected to be between $0.86 \%$ and $10.98 \%$. In contrast, there will be a reduction in Abia, Adamawa, Bauchi, Bayelsa, Benue, Borno, Delta, Ebonyi, Edo, Kaduna, Kogi, Nassarawa, Rivers, Sokoto, Taraba and Zamfara states between $0.41 \%$ and $11.33 \%$.

There are observed changes in the yield of Rice as follows, projected $9.28 \%$ decrease in Adamawa $(\mathrm{P}<0.001), 1.10 \%$ decrease in Anambra (not significant), 6.98\% decrease in Bayelsa $(\mathrm{P}<0.001), 3.04 \%$ decrease in Borno $(\mathrm{P}<0.01), 2.22 \%$ decline in Ekiti $(\mathrm{P}<0.05), 1.41$ decline in Gombe (not significant), $8.80 \%$ decrease in Kaduna $(\mathrm{P}<0.001), 8.72 \%$ decline in Kebbi $(\mathrm{P}<0.001)$, Lagos decreased by $4.03 \%(\mathrm{P}<0.001)$, Ondo went lower by $4.23 \%$ ( $\mathrm{P}<0.001)$ and Yobe decreased by $0.95 \%$ (not significant). The remaining states predicted an increase in Rice yield, which is significant $(\mathrm{P}<0.001)$, with the boost ranging from $0.55 \%$ to $10.94 \%$.

A projected increase in Bauchi, Benue, Ekiti, Kaduna, Kano, Katsina, Kwara, Ondo and Taraba State for Soybean yield is observed. In contrast, a decrease is projected in Adamawa, FCT, Gombe, Kogi, Lagos, Nasarawa, Niger, Oyo, Plateau, and Sokoto State. The changes are significant $(\mathrm{P}<0.001)$ and range from $3.89 \%$ to $11.09 \%$ and $2.82 \%$ and $10.85 \%$ for the projected increase and decrease in yields. These details are contained in Table 4.

\subsection{Crop Yield Changes under NCC Climate Scenario}

In the application of climatic data from the Norwegian Climate Centre (NCC) to model climate change's impact on yields of Cassava, Rice, and Soybean in Nigeria, the following were observed; for Cassava, twenty (20) States projected an increase in their yield (Table 6). This increase is between $1.06 \%$ and $11.01 \%$, significant $(\mathrm{P}<0.001)$. The other sixteen (16) states projected a decline in cassava yield with the observed decrease predicted to range from $1.17 \%$ to $11.52 \%$, also significant $(\mathrm{P}<0.001)$.

In the case of Rice yield, Twenty-one (21) States produced an increase in their yield, while twelve (12) had decreased. $0.32 \%$ to $11.39 \%$ for the increased yield while $0.10 \%$ to $9.70 \%$ for the decline. Most of these predicted increase or decrease in yield is significant $(\mathrm{P}<0.001)$. 
Journal of Digital Food, Energy \& Water Systems, 2 (2): 55-76, 2021

ISSN 2709-4529

(c) Centre for Cyber Physical Food, Energy \& Water Systems

Soybean yield also projected a similar result to those presented above under the NCC climate scenario. Eight (8) States had an increase in yield projected, with these increases going between $4.80 \%$ to $12.23 \%$. All of the projected increases were significant $(\mathrm{P}<0.001)$. The decrease projected is observed in ten (10) states, with them being significant $(\mathrm{P}<0.001)$ except for Ekiti and Akwa Ibom State that are not. The decrease ranged from $0.57 \%$ to $10.78 \%$ across these 10 states.

\subsection{Observation on Crop Yield Changes}

The ensemble means of the climatic parameters obtained from the four (4) Global Climate models (GCMs) were used to estimate the yield of Cassava, Rice, and Soybean across Nigeria, and the result showed that there would be an increase in crop yield in some states. In contrast, some states will experience a decrease.

This scenario presented itself in [32] study. The study reported that future climate projections will positively benefit the united state and negatively affect other regions. Also, [33] and [34] projected an increase in Cassava and Oil Palm yield in Nigeria from 2020 beyond due to the effect of climate change on temperature and precipitation.

Overall, the national average yield of Cassava is projected to increase to 11.23 tonnesha${ }^{1}$ in 2050 and 12.60 tonnesha $^{-1}$ in 2100 ; rice yield has a projected increase to 2.80 tonnesha $^{-1}$ in 2050 and 3.45 tonnesha $^{-1}$ in 2100 , and the yield of cowpea to 0.92 tonnesha ${ }^{-1}$ and 1.18 tonnesha $^{-1}$ in 2050 and 2100 respectively. This portrays that the national average yield of Cassava will increase by 0.07 tonnesha $^{-1}$ in 2050 and by 1.43 tonnesha ${ }^{-1}$ in 2100; rice yield to grow by 0.42 tonnesha $^{-1}$ in 2050 and 1.08 tonnesha $^{-1}$ in 2100 while the national average yield of cowpea to improve by 0.15 tonnesha $^{-1}$ in 2050 and 0.41 tonnesha $^{-1}$ in 2100 . The state by state change in crop yield is shown in figure 2. 
Journal of Digital Food, Energy \& Water Systems, 2 (2): 55-76, 2021

ISSN 2709-4529

(c) Centre for Cyber Physical Food, Energy \& Water Systems

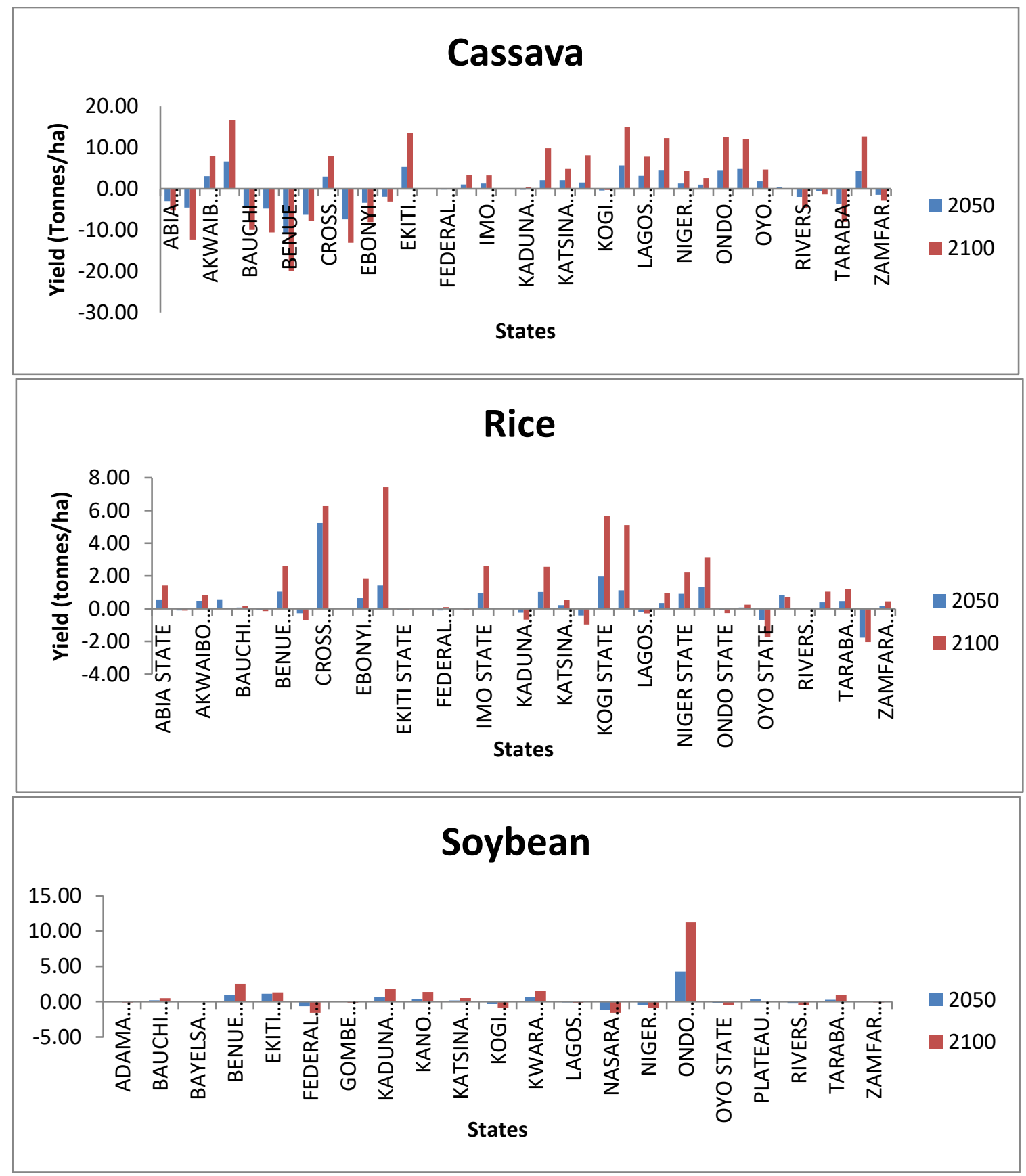

Figure 2: Change in yield of Cassava, Rice and Soybean by the years 2050 and 2100 
Journal of Digital Food, Energy \& Water Systems, 2 (2): 55-76, 2021

ISSN 2709-4529

(C) Centre for Cyber Physical Food, Energy \& Water Systems

From the four (4) scenarios produced using the different climate models, it was observed that in some regions of the country, Nigeria, an increase in crop yield would be experienced as the years go by, while in the other areas, a decrease will be experienced. Studies from different parts of the globe also painted a similar pattern to what was reported above, with [23] postulating a negative impact on crop production due to climate change while [36] reported both an increase and decrease in crop yield as noted in this particular work.

Similarly, [37], including [1], reported that in Europe, climate change would most likely bring about an increase in crop production in future due to a predicted increase in atmospheric carbon dioxide $\left(\mathrm{CO}_{2}\right)$ while on the other hand, agricultural production especially crop production and crop suitability to cultivation are going to experience a decrease where precipitation decreases significantly.

Therefore, we can agree that the issue with climate change is a two-pronged reality activity that comes with both positive and negative effects depending on how extreme it is and what aspect of the climate is more affected.

Table 2: Trend details of crop yield between 1985 - 2100 for ICHEC

\begin{tabular}{|c|c|c|c|c|c|c|}
\hline \multirow[t]{2}{*}{ STATES } & \multicolumn{2}{|c|}{ Cassava } & \multicolumn{2}{|c|}{ Rice } & \multicolumn{2}{|c|}{ Soybean } \\
\hline & $\%$ change & Significance & $\%$ change & Significance & $\%$ change & Significance \\
\hline Abia & -4.87 & $* * *$ & 9.13 & $* * *$ & & \\
\hline Adamawa & -5.86 & $* * *$ & -9.28 & $* * *$ & -4.94 & $* * *$ \\
\hline Akwa Ibom & 9.89 & $* * *$ & 8.41 & $* * *$ & & \\
\hline Anambra & 10.69 & $* * *$ & -0.64 & & & \\
\hline Bauchi & -10.02 & $* * *$ & 0.12 & & 5.19 & $* * *$ \\
\hline Bayelsa & -8.94 & $* * *$ & -5.59 & $* * *$ & & \\
\hline Benue & -8.66 & $* * *$ & 10.94 & $* * *$ & 11.56 & $* * *$ \\
\hline Borno & -11.82 & $* * *$ & -4.80 & $* * *$ & & \\
\hline Cross River & 10.33 & $* * *$ & 9.50 & $* * *$ & & \\
\hline Delta & -11.56 & $* * *$ & & & & \\
\hline Ebonyi & -8.04 & $* * *$ & 9.78 & $* * *$ & & \\
\hline Edo & -3.11 & $* *$ & 9.42 & $* * *$ & & \\
\hline Ekiti & 11.13 & $* * *$ & -1.18 & & -0.87 & \\
\hline Enugu & 3.56 & $* * *$ & & & & \\
\hline$\overline{\mathrm{FCT}}$ & 3.61 & $* * *$ & 1.90 & + & -11.58 & $* * *$ \\
\hline
\end{tabular}


Journal of Digital Food, Energy \& Water Systems, 2 (2): 55-76, 2021

ISSN 2709-4529

(c) Centre for Cyber Physical Food, Energy \& Water Systems

\begin{tabular}{|c|c|c|c|c|c|c|}
\hline Gombe & 8.61 & $* * *$ & -1.36 & & -5.98 & $* * *$ \\
\hline Imo & 10.66 & $* * *$ & 10.60 & $* * *$ & & \\
\hline Kaduna & 1.71 & + & -9.77 & $* * *$ & 12.35 & $* * *$ \\
\hline Kano & 9.07 & $* * *$ & 11.74 & $* * *$ & 9.56 & $* * *$ \\
\hline Katsina & 5.13 & $* * *$ & 9.95 & $* * *$ & 7.91 & $* * *$ \\
\hline Kebbi & 8.92 & $* * *$ & -9.59 & $* * *$ & & \\
\hline Kogi & 3.18 & $* *$ & 7.41 & $* * *$ & -11.35 & $* * *$ \\
\hline Kwara & 10.24 & $* * *$ & 11.20 & $* * *$ & 9.03 & $* * *$ \\
\hline Lagos & 9.26 & $* * *$ & -5.31 & $* * *$ & -3.26 & $* *$ \\
\hline Nasarawa & 10.76 & $* * *$ & 10.54 & $* * *$ & -10.32 & $* * *$ \\
\hline Niger & 6.00 & $* * *$ & 7.34 & $* * *$ & -9.40 & $* * *$ \\
\hline Ogun & 11.14 & $* * *$ & 8.59 & $* * *$ & & \\
\hline Ondo & 10.82 & $* * *$ & -5.84 & $* * *$ & 10.96 & $* * *$ \\
\hline Osun & 11.35 & $* * *$ & 4.98 & $* * *$ & & \\
\hline Oyо & 10.49 & $* * *$ & -3.28 & $* *$ & -6.72 & $* * *$ \\
\hline Plateau & 2.81 & $* *$ & 3.13 & $* *$ & 0.59 & \\
\hline Rivers & -8.95 & $* * *$ & & & & \\
\hline Sokoto & -5.54 & $* * *$ & 8.95 & $* * *$ & -10.16 & $* * *$ \\
\hline Taraba & -8.43 & $* * *$ & 9.06 & $* * *$ & 9.47 & $* * *$ \\
\hline Yobe & 8.95 & $* * *$ & -1.74 & + & & \\
\hline Zamfara & -8.13 & $* * *$ & 8.95 & $* * *$ & & \\
\hline
\end{tabular}

Level of significance: $* * * 0.001, * * 0.01, * 0.05,+0.1$

Table 3: Trend details of crop yield between 1985 - 2100 for NOAA

\begin{tabular}{|l|c|c|c|c|c|c|}
\hline \multicolumn{1}{|c|}{ STATES } & \multicolumn{2}{|c|}{ Cassava } & \multicolumn{2}{c|}{ Rice } & \multicolumn{2}{c|}{ Soybean } \\
\hline & \% change & Significance & \% change & Significance & \% change & Significance \\
\hline Abia & -3.13 & $* *$ & 7.66 & $* * *$ & & \\
\hline Adamawa & -8.29 & $* * *$ & -10.19 & $* * *$ & 0.94 & \\
\hline Akwa Ibom & 7.14 & $* * *$ & 6.00 & $* * *$ & & \\
\hline Anambra & 9.32 & $* * *$ & & & & \\
\hline Bauchi & -8.92 & $* * *$ & 2.75 & $* *$ & 7.92 & $* * *$ \\
\hline Bayelsa & -9.23 & $* * *$ & -2.86 & $* *$ & & \\
\hline
\end{tabular}


Journal of Digital Food, Energy \& Water Systems, 2 (2): 55-76, 2021

ISSN 2709-4529

(c) Centre for Cyber Physical Food, Energy \& Water Systems

\begin{tabular}{|c|c|c|c|c|c|c|}
\hline Benue & -8.17 & $* * *$ & 10.37 & $* * *$ & 10.31 & $* * *$ \\
\hline Borno & -11.69 & $* * *$ & -10.39 & $* * *$ & & \\
\hline Cross River & 9.09 & $* * *$ & 7.88 & $* * *$ & & \\
\hline Delta & -11.06 & $* * *$ & & & & \\
\hline Ebonyi & -4.17 & $* * *$ & 9.64 & $* * *$ & & \\
\hline Edo & -2.88 & $* *$ & 6.95 & $* * *$ & & \\
\hline Ekiti & 9.75 & $* * *$ & -1.71 & + & -1.36 & \\
\hline Enugu & 2.86 & $* *$ & & & & \\
\hline FCT & 4.15 & $* * *$ & -0.47 & & -10.68 & $* * *$ \\
\hline Gombe & 8.50 & $* * *$ & -0.62 & & -5.09 & $* * *$ \\
\hline Imo & 9.23 & $* * *$ & 10.54 & $* * *$ & & \\
\hline Kaduna & -0.17 & & -7.87 & $* * *$ & 11.86 & $* * *$ \\
\hline Kano & 8.57 & $* * *$ & 11.39 & $* * *$ & 8.80 & $* * *$ \\
\hline Katsina & 3.70 & $* * *$ & 9.27 & $* * *$ & 4.80 & $* * *$ \\
\hline Kebbi & 8.09 & $* * *$ & -8.99 & $* * *$ & & \\
\hline Kogi & -1.22 & & 7.37 & $* * *$ & -10.36 & $* * *$ \\
\hline Kwara & 8.61 & $* * *$ & 10.16 & $* * *$ & 8.41 & $* * *$ \\
\hline Lagos & 7.88 & $* * *$ & 0.50 & & -1.18 & \\
\hline Nasarawa & -10.96 & $* * *$ & & & & \\
\hline Niger & 6.59 & $* * *$ & 7.17 & $* * *$ & -8.64 & $* * *$ \\
\hline Ogun & 11.33 & $* * *$ & 6.84 & $* * *$ & & \\
\hline Ondo & 9.83 & $* * *$ & -4.54 & $* * *$ & 10.93 & $* * *$ \\
\hline Osun & 9.95 & $* * *$ & 4.43 & $* * *$ & & \\
\hline Oуо & 8.35 & $* * *$ & -0.55 & & -4.21 & $* * *$ \\
\hline Plateau & 0.69 & & 4.19 & $* * *$ & 1.85 & + \\
\hline Rivers & -8.75 & $* * *$ & & & & \\
\hline Sokoto & -4.69 & $* * *$ & 10.25 & $* * *$ & -10.71 & $* * *$ \\
\hline Taraba & -7.74 & $* * *$ & 8.31 & $* * *$ & 8.45 & $* * *$ \\
\hline Yobe & 11.31 & $* * *$ & -2.89 & $* *$ & & \\
\hline Zamfara & -6.46 & $* * *$ & -5.97 & $* * *$ & & \\
\hline
\end{tabular}

Level of significance: $* * * 0.001, * * 0.01, * 0.05,+0.1$ 
Journal of Digital Food, Energy \& Water Systems, 2 (2): 55-76, 2021

ISSN 2709-4529

(c) Centre for Cyber Physical Food, Energy \& Water Systems

Table 4: Trend details of crop yield between 1985 - 2100 for MIROC

\begin{tabular}{|c|c|c|c|c|c|c|}
\hline \multirow[t]{2}{*}{ STATES } & \multicolumn{2}{|c|}{ Cassava } & \multicolumn{2}{|c|}{ Rice } & \multicolumn{2}{|c|}{ Soybean } \\
\hline & $\%$ change & Significance & \% change & Significance & $\%$ change & Significance \\
\hline Abia & -4.87 & $* * *$ & 9.13 & $* * *$ & & \\
\hline Adamawa & -5.86 & $* * *$ & -9.28 & $* * *$ & -4.94 & $* * *$ \\
\hline Akwa Ibom & 9.58 & $* * *$ & 4.14 & $* * *$ & & \\
\hline Anambra & 8.87 & $* * *$ & -1.10 & & & \\
\hline Bauchi & -10.21 & $* * *$ & 2.34 & $*$ & 4.57 & $* * *$ \\
\hline Bayelsa & -8.74 & $* * *$ & -6.98 & $* * *$ & & \\
\hline Benue & -8.11 & $* * *$ & 10.38 & $* * *$ & 9.86 & $* * *$ \\
\hline Borno & -11.33 & $* * *$ & -3.04 & $* *$ & & \\
\hline Cross River & 9.22 & $* * *$ & 8.07 & $* * *$ & & \\
\hline Delta & -10.89 & $* * *$ & & & & \\
\hline Ebonyi & -7.21 & $* * *$ & 8.21 & $* * *$ & & \\
\hline Edo & -3.13 & $* *$ & 9.95 & $* * *$ & & \\
\hline Ekiti & 9.66 & $* * *$ & -2.22 & $*$ & 3.89 & $* * *$ \\
\hline Enugu & 3.85 & $* * *$ & & & & \\
\hline FCT & -1.23 & & 0.81 & & -10.61 & $* * *$ \\
\hline Gombe & 7.24 & $* * *$ & -1.41 & & -5.65 & $* * *$ \\
\hline Imo & 9.14 & $* * *$ & 10.25 & $* * *$ & & \\
\hline Kaduna & 0.86 & & -8.80 & $* * *$ & 11.09 & $* * *$ \\
\hline Kano & 8.71 & $* * *$ & 10.79 & $* * *$ & 9.34 & $* * *$ \\
\hline Katsina & 4.74 & $* * *$ & 9.41 & $* * *$ & 6.12 & $* * *$ \\
\hline Kebbi & 7.73 & $* * *$ & -8.72 & $* * *$ & & \\
\hline Kogi & -0.41 & & 6.22 & $* * *$ & -10.85 & $* * *$ \\
\hline Kwara & 6.66 & $* * *$ & 8.99 & $* * *$ & 7.37 & $* * *$ \\
\hline Lagos & 10.26 & $* * *$ & -4.03 & $* * *$ & -2.93 & $* *$ \\
\hline Nasarawa & 8.52 & $* * *$ & 10.12 & $* * *$ & -9.05 & $* * *$ \\
\hline Niger & 3.53 & $* * *$ & 4.96 & $* * *$ & -7.37 & $* * *$ \\
\hline Ogun & 10.98 & $* * *$ & 8.49 & $* * *$ & & \\
\hline Ondo & 7.21 & $* * *$ & -4.23 & $* * *$ & 10.58 & $* * *$ \\
\hline Osun & 9.93 & $* * *$ & 1.53 & & & \\
\hline Оуо & 8.39 & $* * *$ & 0.55 & & -6.66 & $* * *$ \\
\hline
\end{tabular}


Journal of Digital Food, Energy \& Water Systems, 2 (2): 55-76, 2021

ISSN 2709-4529

(c) Centre for Cyber Physical Food, Energy \& Water Systems

\begin{tabular}{|l|c|c|c|c|c|c|}
\hline Plateau & -0.99 & & 4.72 & $* * *$ & -2.82 & $* *$ \\
\hline Rivers & -8.52 & $* * *$ & & & & \\
\hline Sokoto & -6.69 & $* * *$ & 10.07 & $* * *$ & -8.95 & $* * *$ \\
\hline Taraba & -6.53 & $* * *$ & 9.70 & $* * *$ & 10.15 & $* * *$ \\
\hline Yobe & 10.72 & $* * *$ & -0.95 & & & \\
\hline Zamfara & -5.45 & $* * *$ & 10.94 & $* * *$ & & \\
\hline
\end{tabular}

Level of significance: *** $0.001, * * 0.01, * 0.05,+0.1$

Table 5: Trend details of crop yield between $1985-2100$ for NCC

\begin{tabular}{|c|c|c|c|c|c|c|}
\hline \multirow[t]{2}{*}{ STATES } & \multicolumn{2}{|c|}{ Cassava } & \multicolumn{2}{|c|}{ Rice } & \multicolumn{2}{|c|}{ Soybean } \\
\hline & $\%$ change & Significance & $\%$ change & Significance & $\%$ change & Significance \\
\hline Abia & -3.34 & $* * *$ & 8.06 & *** & & \\
\hline Adamawa & -7.37 & $* * *$ & -9.70 & $* * *$ & -1.26 & \\
\hline Akwa Ibom & 7.21 & $* * *$ & 3.16 & $* *$ & & \\
\hline Anambra & 9.36 & $* * *$ & & & & \\
\hline Bauchi & -9.63 & $* * *$ & 3.00 & $* *$ & 6.49 & $* * *$ \\
\hline Bayelsa & -7.42 & $* * *$ & -6.77 & $* * *$ & & \\
\hline Benue & -6.05 & **** & 11.39 & $* * *$ & 10.77 & $* * *$ \\
\hline Borno & -11.52 & $* * *$ & -7.68 & $* * *$ & & \\
\hline Cross River & 10.28 & $* * *$ & 8.07 & **** & & \\
\hline Delta & -10.98 & **** & & & & \\
\hline Ebonyi & -7.30 & $* * *$ & 9.09 & $* * *$ & & \\
\hline Edo & -2.59 & $* *$ & 5.02 & *** & & \\
\hline Ekiti & 9.13 & **** & -2.68 & $* *$ & -0.57 & \\
\hline Enugu & 1.67 & + & & & & \\
\hline FCT & -1.40 & & 1.12 & & -10.78 & $* * *$ \\
\hline Gombe & 8.83 & **** & -0.10 & & -3.32 & $* * *$ \\
\hline Imo & 9.90 & $* * *$ & 9.09 & *** & & \\
\hline Kaduna & 1.06 & & -8.34 & $* * *$ & 12.23 & $* * *$ \\
\hline Kano & 9.20 & $* * *$ & 10.98 & $* * *$ & 7.69 & $* * *$ \\
\hline Katsina & 2.41 & $*$ & 9.57 & $* * *$ & 4.80 & $* * *$ \\
\hline Kebbi & 8.47 & $* * *$ & -8.88 & $* * *$ & & \\
\hline
\end{tabular}


Journal of Digital Food, Energy \& Water Systems, 2 (2): 55-76, 2021

ISSN 2709-4529

(c) Centre for Cyber Physical Food, Energy \& Water Systems

\begin{tabular}{|c|c|c|c|c|c|c|}
\hline Kogi & -1.17 & & 6.48 & $* * *$ & -9.80 & $* * *$ \\
\hline Kwara & 6.11 & $* * *$ & 8.83 & $* * *$ & 8.27 & $* * *$ \\
\hline Lagos & 8.45 & $* * *$ & -1.52 & & -5.14 & $* * *$ \\
\hline Nasarawa & 7.96 & $* * *$ & 8.18 & $* * *$ & & \\
\hline Niger & 2.40 & $*$ & 4.09 & $* * *$ & -8.33 & $* * *$ \\
\hline Ogun & 10.09 & $* * *$ & 7.46 & $* * *$ & & \\
\hline Ondo & 8.29 & $* * *$ & 0.32 & & 10.36 & $* * *$ \\
\hline Osun & 9.38 & $* * *$ & 6.59 & $* * *$ & & \\
\hline Oyo & 10.07 & $* * *$ & -2.09 & $*$ & -6.38 & $* * *$ \\
\hline Plateau & -2.25 & $*$ & 4.71 & $* * *$ & -1.67 & + \\
\hline Rivers & -6.85 & $* * *$ & & & & \\
\hline Sokoto & -3.04 & $* *$ & 9.72 & $* * *$ & -10.24 & $* * *$ \\
\hline Taraba & -7.34 & $* * *$ & 8.36 & $* * *$ & 8.70 & $* * *$ \\
\hline Yobe & 11.01 & $* * *$ & -1.93 & + & & \\
\hline Zamfara & -6.40 & $* * *$ & -5.04 & $* * *$ & & \\
\hline
\end{tabular}

Level of significance: $* * * 0.001, * * 0.01, * 0.05,+0.1$

\subsection{National Mean Crop Yield}

Climate change's impact on Cassava, Rice, and soybean yields was further modeled on a National basis against the state-by-state basis presented in Tables $2-5$. The result is shown in Table 6.

Table 6: National Mean Crop Yield Trend between 1985 - 2100

\begin{tabular}{|l|c|c|c|c|c|c|}
\hline & \multicolumn{2}{|c|}{ Cassava } & \multicolumn{2}{c|}{ Rice } & \multicolumn{2}{c|}{ Soybean } \\
\hline Model & \% change & Significance & \% change & Significance & \% change & Significance \\
\hline ICHEC & 3.91 & $* * *$ & 8.88 & $* * *$ & 2.81 & $* *$ \\
\hline MAROC & 0.08 & & 7.77 & $* * *$ & 5.84 & $* * *$ \\
\hline NOAA & 1.70 & + & 6.62 & $* * *$ & 11.38 & $* * *$ \\
\hline NCC & -0.93 & & 8.85 & $* * *$ & 9.06 & $* * *$ \\
\hline
\end{tabular}

Level of significance: $* * * 0.001, * * 0.01, * 0.05,+0.1$ 
Journal of Digital Food, Energy \& Water Systems, 2 (2): 55-76, 2021

ISSN 2709-4529

(c) Centre for Cyber Physical Food, Energy \& Water Systems

Results presented showed an increase of $3.91 \%(\mathrm{P}<0.001), 0.08,1.79(\mathrm{P}<0.1)$ and a decrease of $0.93 \%$ for cassava yield from 1985 - 2100 using climatic data from ICHEC, MIROC, NOAA, and NCC, respectively. It also projected an increase in yield of $8.88 \%$ $(\mathrm{P}<0.001), 7.77 \%(\mathrm{P}<0.001), 6.62 \%(\mathrm{P}<0.001)$, and $8.85 \%(\mathrm{P}<0.001)$ for Rice yield under the period from 1985 - 2100 using climatic data from ICHEC, MIROC, NOAA, and NCC respectively.

In the case of Soybean, an increase in yield is predicted using the four (4) climatic scenarios. The rate of increase are $2.81 \%(\mathrm{P}<0.01), 5.84 \%(\mathrm{P}<0.001), 11.38(\mathrm{P}<0.001)$ and $9.06 \%(\mathrm{P}<0.001)$ for ICHEC, MIROC, NOAA and NCC respectively.

These projected changes are still well below acceptable global standards to achieve food security. The above finding agrees with [38], where it was reported that due to the predicted increase in food demand worldwide by 2050 , there must be incremental yield, needing more to be done to meet the targeted approximate $20 \%$ increase in the yield of crops to tackle food sufficiency. Research [34] also concluded that the net impact of climate change on oil palm yield in the Niger Delta region of Nigeria is positive, in line with the positive effects of climate change on the yield of crops considered for this study. The impact of temperature and solar radiation on the decrease in rice yield has been widely reported as the decades go by [39]. This study appears to negate the finding, although the study was carried out at a regional scale while this study was on a national scale.

\section{Conclusion}

The impact of climate change on crop yield in Nigeria has been modelled using Cassava, Rice, and Soybean over three time periods, applying climatic data from four (4) GCMs in the process. It was shown how climate change positively impacted the predicted yields of these crops in the future; in some regions or states in the country, the crops will experience an uptick in yield as opposed to the downward trend observed in some regions of Nigeria. In all, the research showed that as the years go by, the yield of Cassava, Rice, and Soybean in Nigeria is projected to increase; this outlook portrays a swing in the right direction as regards the attainment of food sufficiency and security in the country. However, this positive result did not consider how other factors necessary for crop production, such as management practices, planting area, crop species, and cost of security, will impact yield. Further work can also be done to determine how water use will affect the production of these crops in the future over this same study area. 
Journal of Digital Food, Energy \& Water Systems, 2 (2): 55-76, 2021

ISSN 2709-4529

(c) Centre for Cyber Physical Food, Energy \& Water Systems

This study also demonstrated how the use of empirical models to estimate and model the future yield of crops can be relied upon based on the similarities the results from this study, largely, has with results from other studies that modeled the impact of climate change on crops using different approaches. These studies applied approaches different from the one used for this study to model the impact of climate change on crop yield across the world. Therefore, the knowledge provided here can assist policymakers and researchers to adequately enact policies and birth plans that can be implemented to improve crop production.

\section{References}

[1] Lazar Tanasijevic. (2011). Assessing Impacts of Climate Change on Crop Water and Irrigation Requirements in the Mediterranean. Master of Science IAMB / Thèse Master of Science n. 615, Bari, CIHEAM/IAMB, 2011.

[2] Oguntunde, P. G., Jan Friesen, Nick van de Giesen and Hubert, H. G. Savenije. (2006). Hydroclimatology of the Volta River Basin in West Africa: Trends and Variability from 1901 to 2006, Physics and Chemistry of the Earth 31, $1180-1188$.

[3] Oguntunde, P. G., Abiodun, B. J. and Lischeid, G. (2011). Rainfall trends in Nigeria, 19012000. Journal of Hydrology, 411, pp. 207-218.

[4] Tubiello, F., Soussana, J. F., Howden, S. M., and Easterling, W. (2007). Crop and Pasture Response to Climate Change. PNAS, Volume 104, pp19686-19690.

[5] IPCC. (2007). Summary for policymakers. In Climate Change 2007: The Physical Science Basis. Contribution of Working Group I to the 4th Assessment Report of the Intergovernmental Panel on Climate Change. Cambridge, U.K.: Cambridge University Press.

[6] Morton, O. (2007). Climate change: is this what it takes to save the world? Nature, Volume 447 (7141), pp132-136.

[7] Ajewole Davies Ojo \& Iyanda Sadiq (2010). Effect of Climate Change on Cocoa Yield: A Case of Cocoa Research Institute (CRIN) farm, Oluyole Local Government Ibadan, Oyo state. Journal of Sustainable Development in Africa, Volume 12, No.1

[8] Valizadeh, J., Ziaei, S.M. and Mazloumzadeh, S.M. (2014). Assessing climate change impacts on wheat production (a case study). Journal of the Saudi Society of Agricultural Sciences (2014) 13, 107-115. http://dx.doi.org/10.1016/j.jssas.2013.02.002

[9] Tao, F., Zhang, Z., Liu, j. And Yokozawa, M.(2009). Modelling the impacts of weather and climate variability on crop productivity over a large area: A new super-ensemble-based probabilistic projection. Agricultural and Forest Meteorology 149, 1266-1278.

[10] Roudier, P., Sultan, B., Philippe Quirion, P., Berg, A. (2011). The impact of future climate change on West African crop yields: What does the recent literature say? Global Environmental Change 21, pp1073-1083. 
Journal of Digital Food, Energy \& Water Systems, 2 (2): 55-76, 2021

ISSN 2709-4529

(c) Centre for Cyber Physical Food, Energy \& Water Systems

[11] Obot, A. I., Osaretin, F. I. and Mamuro, G. O. (2021). Spatiotemporal variability of soil moisture under different soil groups in Etsako West Local Government Area, Edo State, Nigeria. Journal of the Saudi Society of Agricultural Sciences - Article in Press https://doi.org/10.1016/j.jssas.2021.07.006

[12] Tao, F., Hayashi, Y., Zhang, Z., Sakamoto, T., Yokozawa, M., (2008). Global Warming, Rice Production and Water Use In China: Developing A Probabilistic Assessment. Agric. For. Meteorol. 148, pp94-110.

[13] Adebayo, O.B., Osunbitan, J.A., Adekalu, O.K. and Okunade, D.A. (2009). Evaluation of FAO-56 Penman- Monteith and Temperature Based Models in Estimating Reference Evapotranspiration Using Complete and Limited Data, Application to Nigeria. Agricultural Engineering International: The CIGR Ejournal. Manuscript number 1291. Volume XI.

[14] Ilesanmi, O. A., Oguntunde, P. G. and Olufayo, A. A. (2014). Evaluation of four evapotranspiration models for IITA stations in Ibadan, Onne and Kano, Nigeria. J. Environ. Earth Sci., 4 (5) (2014), pp. 89-97

[15] Ramirez-Villegas, J., Jarvis, A. \& Läderach, P. (2013). Empirical approaches for assessing impacts of climate change on agriculture: The EcoCrop model and a case study with grain sorghum. Agricultural and Forest Meteorology. DOI: 10.1016/j.agrformet2011.09.005.

[16] Mora, C., Frazier, A.G., Longman, R.J., Dacks, R.S., Walton, M.M., Tong, E.J., Sanchez, J.J., Kaiser, L.R., et al. (2013). The projected timing of climate departure from recent variability. Nature. 502 (7470):183-187. DOI: 10.1038/nature12540.

[17] IPCC. (2013). Summary for Policymakers. In: Climate Change 2013: The Physical Science Basis. Contribution of Working Group I to the Fifth Assessment Report of the Intergovernmental Panel on Climate Change [Stocker, T.F., D. Qin, G.-K. Plattner, M. Tignor, S. K. Allen, J. Boschung, A. Nauels, Y. Xia, V. Bex and P.M. Midgley (eds.)]. Cambridge University Press, Cambridge, United Kingdom and New York, NY, USA.

[18] Kang, Y., Khan, S., and Maa, X. (2009). Climate Change Impacts on Crop Yield, Crop Water Productivity and Food Security - A Review. Progress in Natural Science 19, 16651674. doi:10.1016/j.pnsc.2009.08.001

[19] Rosenzweig, C. and Parry, M.L. (1994). Potential Impact of Climate Change on World Food Supply. Nature volume 367, pp133-138.

[20] Parry, M.L., Rosenzweig, C., Iglesias, A., Livermore, M. and Fischer, G. (2004). Effects of Climate Change on Global Food Production Under SRES Emissions And Socio-Economic Scenarios. Global Environmental Change, Volume 14, pp53-67.

[21] Paustian, K., Ojima, D., Kelly, R., Lackett, J., Tubiello, F., Brown, R., Izaurralde, C., Jagtap, S. and Li,C. (2000). Crop Model Analysis of Climate and CO2 Effects, Workshop Report. Natural Resource Ecology Laboratory, Colorado State University.

[22] Cabas, J., Weersink, A. and Olale, E. (2009). Crop Yield Response to Economic, Site and Climatic Variables. Climatic Change, Volume 101, Numbers 3-4, pp599-616.

[23] Olubanjo, O. O. and Alade, A. E. (2018). Effect of Climate Variability on the Yield of Crops in Ondo State, Nigeria. International Journal of Water Resources and Environmental Engineering, Vol. 10(5), pp. 54-63. DOI: 10.5897/IJWREE2018.0783 
Journal of Digital Food, Energy \& Water Systems, 2 (2): 55-76, 2021

ISSN 2709-4529

(c) Centre for Cyber Physical Food, Energy \& Water Systems

[24] Dyah, R. P., Kei M. and Bambang, H. T.(2013). The dynamics of rice production in Indonesia 1961-2009. Journal of the Saudi Society of Agricultural Sciences (2013) 12, 27 37. http://dx.doi.org/10.1016/j.jssas.2012.05.002

[25] Boko, M., I. Niang, A. Nyong, C. Vogel, A. Githeko, M. Medany, B. Osman-Elasha, R. Tabo and P. Yanda, (2007): Africa. Climate Change 2007: Impacts, Adaptation and Vulnerability. Contribution of Working Group II to the Fourth Assessment Report of the Intergovernmental Panel on Climate Change, M.L. Parry, O.F. Canziani, J.P. Palutikof, P.J. van der Linden and C.E. Hanson, Eds. Cambridge University Press, Cambridge UK, 433467.

[26] Harris, I., Jones, P.D., Osborn, T.J. \& Lister, D.H. (2014). Updated high-resolution grids of monthly climatic observations - the CRU TS3.10 Dataset International Journal of Climatology. 34(3):623-642. DOI: 10.1002/joc.3711

[27] Bum Kim, K., Kwon, H-H., Han, D. (2021). Intercomparison of joint bias correction methods for precipitation and flow from a hydrological perspective, Journal of Hydrology (2021), doi: https://doi.org/10.1016/j.jhydrol.2021.127261

[28] Chen, J., Arsenault, R., Brissette, F. P., \& Zhang, S. (2021). Climate change impact studies: Should we bias correct climate model outputs or post-process impact model outputs? Water Resources Research, 57, e2020WR028638. https://doi.org/10.1029/2020WR028638

[29] Qian, B., Jong, R. D., Warren, R., Chipanshi, A. \& Hill, H. (2009). Statistical spring wheat yield forecasting for the Canadian prairie provinces. Agricultural and Forest Meteorology $149,1022-1031$.

[30] Matsumura, K., Gaitan, C. F., Sugimoto, K., Cannon, A. J. and HSIEH, W. W. (2015). Maize yield forecasting by linear regression and artificial neural networks in Jilin, China. Journal of Agricultural Science (2015), 153, 399-410. doi:10.1017/S0021859614000392

[31] Salmi, T., Maatta, A., Anttila, P., Ruoho-Airola, T. and Amnell, T. (2002). Detecting Trends of Annual Values of Atmospheric Pollutants by the Mann-Kendall Test and Sen's Slope Estimates. Publications on Air Quality, vol. 31. Helsinki, Finland.

[32] Tubiello, F.N., Rosenzweig, C., Goldberg, R. A., Jagtap, S. and Jones, J.W. (2000). Effects of Climate Change on U.S. Crop Production Part I: Wheat, Potato, Corn, and Citrus. U.S. National Assessment Technical Report.

[33] Mereu, V., Carboni, G., Gallo, A., Cervigni, R., Spano, D. (2015). Impact of climate change on staple food crop production in Nigeria. Climatic Change 132, 321-336. https://doi.org/10.1007/s10584-015-1428-9

[34] Okoro, S. U., Schickhoffa, U., Boehnera,I. J., Schneiderb, U. A. and Huth, N.I. (2017). Climate impacts on palm oil yields in the Nigerian Niger Delta Global Environmental Change. Europ. J. Agronomy 85 (2017) 38-50. https://doi.org/10.1007/s10584-015-1428-9

[35] Zhao, C., Liu, B., Piao, S., Wang, X., Lobell, D. B., Huang, Y., . . Ciais, P. (2017). Temperature increase reduces global yields of major crops in four independent estimates. Proceedings of the National Academy of Sciences, 114, 9326-9331. https://doi.org/10.1073/pnas.1701762114

[36] He,W., Yang, J.Y., Qian, B., Drury, C.F., Hoogenboom, G., He, P., Lapen, D. and Zhou,W. (2018) Climate change impacts on crop yield, soil water balance and nitrate leaching in the 
Journal of Digital Food, Energy \& Water Systems, 2 (2): 55-76, 2021

ISSN 2709-4529

(c) Centre for Cyber Physical Food, Energy \& Water Systems

semiarid and humid regions of Canada. PLoS ONE 13(11): e0207370. https://doi.org/10.1371/journal.pone.0207370

[37] Olesen J. E. and Bindi M. (2002). Consequences of Climate Change for European Agricultural Productivity, Land Use and Policy. European Journal of Agronomy. 16(4): $239-262$.

[38] Kumar Lakshmi, T. V., Barbosa Humberto, Madhu, S. and Koteswara Rao, K. (2019). Studies on Crop Yields and Their Extreme Value Analysis over India. Sustainability 2019, 11, 4657; doi:10.3390/su11174657

[39] Oguntunde, P.G., Lischeid, G. and Dietrich, O. (2017). Relationship between Rice Yield and Climate Variables in Southwest Nigeria Using Multiple Linear Regression and Support Vector Machine Analysis. International Journal of Biometeorology, 62, 459-469. https://doi.org/10.1007/s00484-017-1454-6 